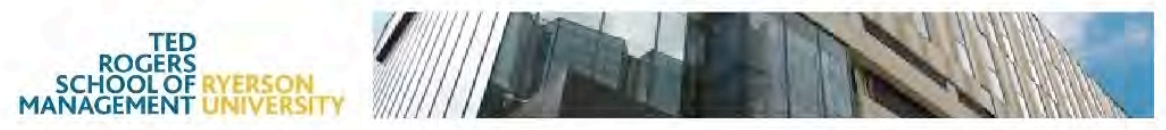

\title{
Questions about 'Next Gen' Broadband Inspired by Australia's NBN
}

\author{
Catherine Middleton \\ Ryerson University \\ 2010 ITS Biennial Conference
}

Slides may be reproduced with attribution. 


\section{Two objectives today}

- Overview of NBN progress to date

- Big picture view

- Discussion of (a few) questions raised by the NBN case

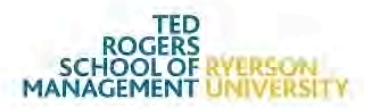




\section{Australia's NBN}

http://www.nbn.gov.au/sites/all/files/TVC/overview.html 


\section{Did You Catch Those Details?}

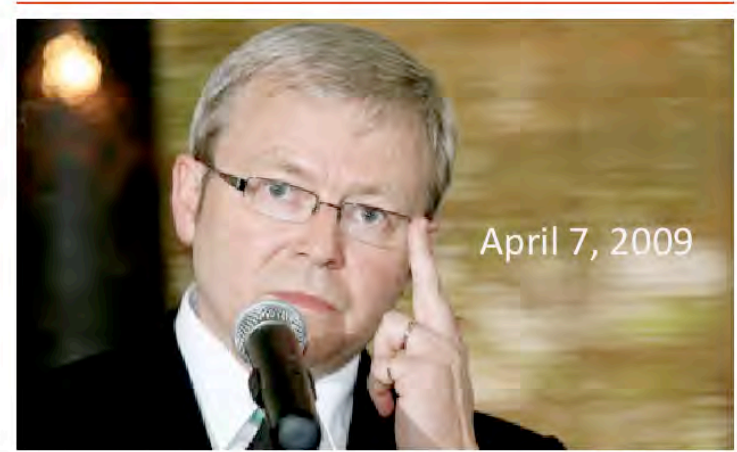

Kevin Rudd: 'Superfast national broadband network is the most ambitious, far-reaching ifrastructure project undertaken by an Australian govemment.' Photograph: Adek Berry/AFP/Getty Images

The Australian government today launched an ambitious plan to make Australia one of the world's most wired countries in a massive project to extend broadband internet access across the country.

ITS Biennial Conference
- $\$ 43$ billion investment (public/private)

- FTTH to $90 \%$ of premises, up to $100 \mathrm{Mbps}$

- Fixed wireless or satellite to remaining $10 \%$, up to $12 \mathrm{Mbps}$

- 8 year rollout plan ROGERS SCHOOLOF RYERSON

Rudd, K. (2009). New National Broadband Network. http:// www.minister.dbcde.gov.au/media/media_releases/2009/022 


\section{Need for Regulatory Reform}

- Department of Broadband Communications and the Digital Economy (2009). National Broadband Network: Regulatory Reform for 21st Century Broadband Discussion Paper.

- National Broadband Network Companies Bill 2010 and Telecommunications Legislation Amendment (National Broadband Network Measures-Access Arrangements) Bill 2010 (not passed)

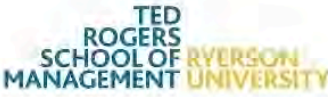

http://www.dbcde.gov.au/_data/assets/pdf_file/0006/110013/

NBN_Regulatory_Reform_for_the_21st_Century_Broadband_low_res_web.pdf.

http://www.dbcde.gov.au/_data/assets/pdf_file/0003/125895/Explanatory_notesNBN_Companies_Bill_2010_and_Telecommunications_Legislation_Amendment_Bill_ 2010.pdf. (accessed 15 May 2010) 


\section{$9+$ months later...}

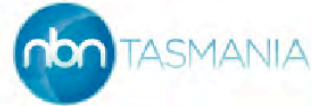

- NBN Tasmania Ltd

- Network will go live in 3 towns in TAS in July, \$100M invested

- Plans to connect $100 \mathrm{~K}$ households
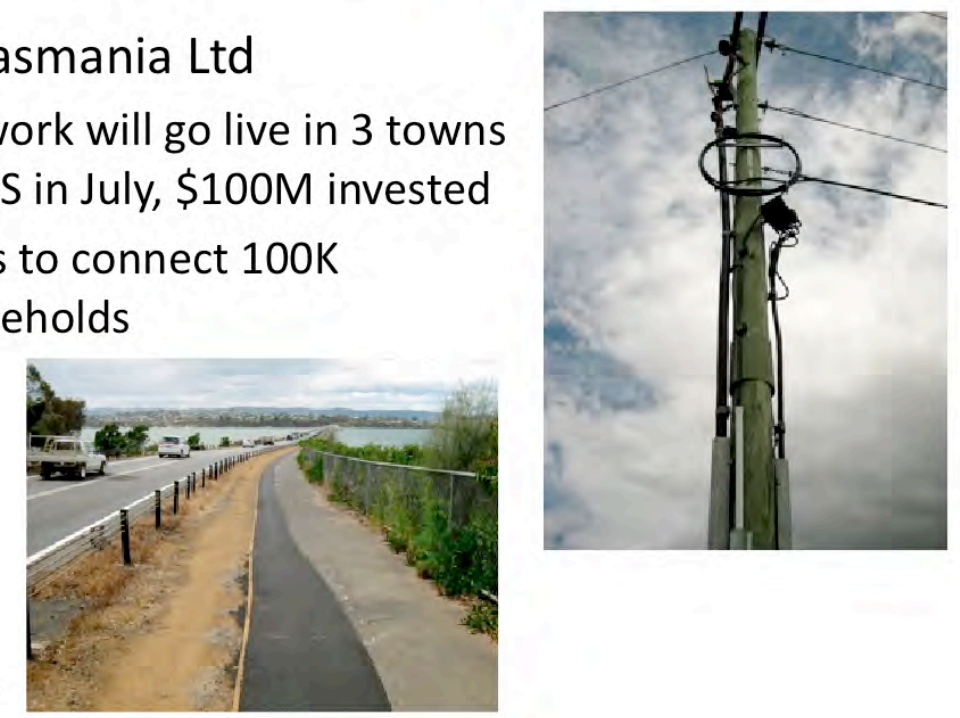

Photos by Catherine Middleton, December 2009.

Lower left: Pavement cut where fibre connecting Aurora Energy's Cambridge Data Centre with pilot site at Midway Point, TAS.

Right: Aerial fibre installation near Cambridge Data Centre. 


\section{4 months later...}

- NBN Co Ltd (www.nbnco.com.au)

- 'GBE', 150 employees, \$212 million in government funds

- Planning open access wholesale fibre network, layer 2 bitstream access

- $6000 \mathrm{~km}$ backbone under construction

-5 mainland test sites soon underway

- Consultation with industry \& community

- etc...

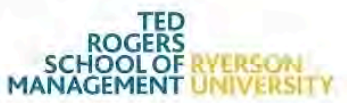

Quigley, M. (2010). Testimony at Public Hearing: Senate Select Committee on the National Broadband Network, Canberra, 15 April. http://www.aph.gov.au/hansard/ senate/commttee/S12976.pdf. (accessed 10 May 2010).

NBN Co Limited (2009). NBN Co Consultation Paper: Proposed Wholesale Fibre Bitstream Products. http://www.nbnco.com.au/content/upload/files/ NBN001_concept_paper_final.pdf. (accessed 31 January 2010).

NBN Co Limited (2010). NBN Co Response to Industry Submissions - Proposed Wholesale Fibre Bitstream Products. Sydney: NBNCo Limited. http:// www.nbnco.com.au/content/upload/files/Response_to_Industry_Submissions/ NBN_Co_response_to_consultation_submissions.pdf. (accessed 5 May 2010).

See also Comms Alliance NBN site: http://commsalliance.com.au/Activities/nbn 


\section{Implementation Study}

- McKinsey \& Company and KPMG (2010). National Broadband Network Implementation Study - released May 2010, 546 pp., \$25M

- Asked to advise on implementing NBN policy

- Government 'plan' to date $=$ media release +8 page glossy brochure

- Concludes plan is feasible, approx. cost $\$ 43 \mathrm{~B}$, fibre to $93 \%$, wireless to $4 \%$, satellite to $3 \%$, can go ahead without Telstra
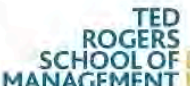

MANAGEMENT UNIVERSITY

McKinsey \& Company, \& KPMG (2010). National Broadband Network Implementation Study. http://data.dbcde.gov.au/nbn/NBN-Implementation-Study-completereport.pdf

See also Given, J. (2010). Inside Conroy's Implement. http://inside.org.au/insideconroys-implement/ 


\section{So far, so good?}

- "where faith and politics take over"?

- About politics...

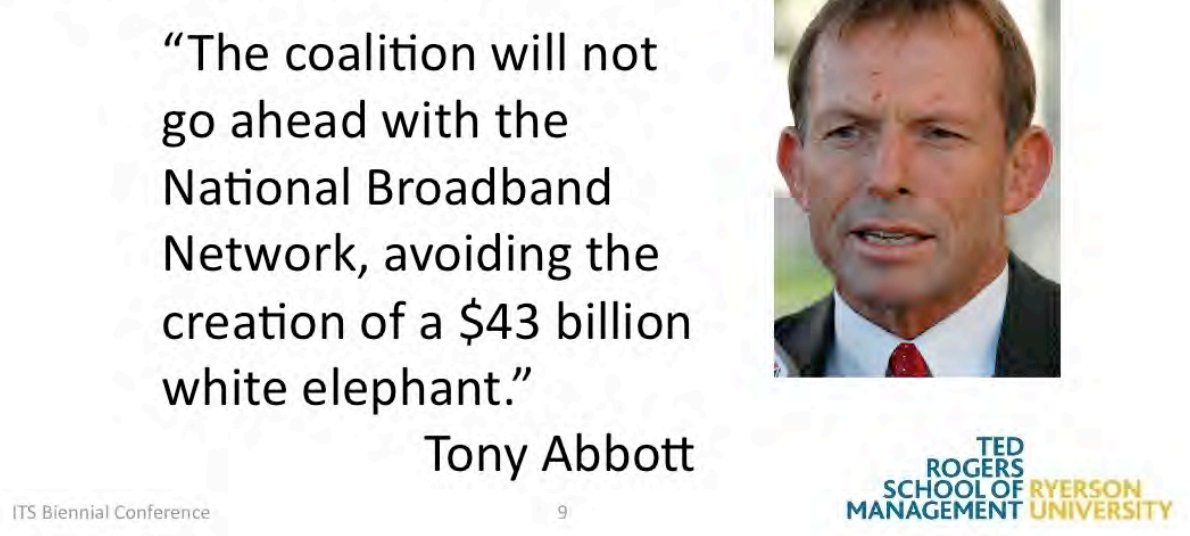

Faith and politics quote: Given, J. (2010). Inside Conroy's Implement. http:// inside.org.au/inside-conroys-implement/. (accessed 16 May 2010).

Abbott image: http://media.stylespress.com/auscon/people/tony-abbott-400x586.jpg Abbott, T. (2010). Votes and Proceedings Hansard, Thursday 13 May 2010. Canberra: House of Representatives. http://www.aph.gov.au/hansard/reps/dailys/dr130510.pdf. (accessed 16 May 2010).

Senate committee also recommends cancelling the project: Senate Select Committee on the National Broadband Network (2010). Fourth Interim Report. Canberra:

Commonwealth of Australia. http://www.aph.gov.au/Senate/committee/ broadband_ctte/interim4-report/index.htm. (accessed 20 May 2010). 


\section{More about politics: Enter PM Gillard}

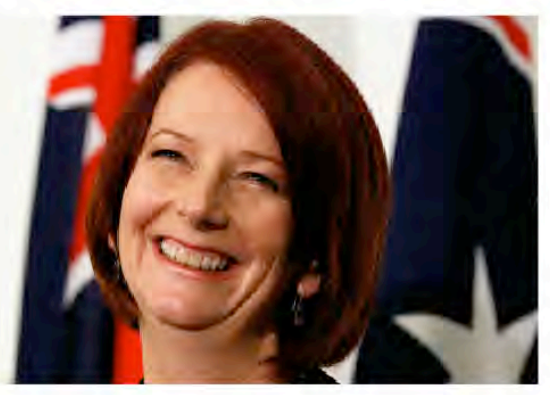

And some good news from the departing

PM: "Agreement between NBN Co and

Telstra on the rollout of the National

Broadband Network"

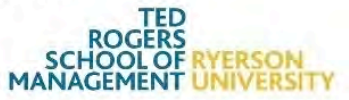

Gillard image: http://static.guim.co.uk/sys-images/Guardian/Pix/pictures/ 2010/6/24/1277412532177/Julia-Gillard--005.jpg

One agreement, 3 press releases:

1. Rudd, K., Tanner, L., \& Conroy, S. (2010). Agreement between NBN Co and Telstra on the Rollout of the National Broadband Network. http://

www.minister.dbcde.gov.au/media/media_releases/2010/060.

2. Telstra (2010). Telstra Signs Financial Heads of Agreement on NBN. http:// www.telstra.com.au/abouttelstra/media-centre/announcements/telstra-signsfinancial-heads-of-agreement-on-nbn-1.xml. (accessed 21 June 2010).

3. NBN Co Limited (2010). NBN Co and Telstra Reach Heads of Agreement. http:// www.nbnco.com.au/publications-and-announcements/latest-announcements/ doc/nbn-co-and-telstra-reach-heads-of-agreement. (accessed 27 June 2010). 


\section{So:}

? Reduced likelihood of electoral defeat

$\checkmark$ In-principle deal with Telstra

$\checkmark$ Implementation plan confirming feasibility

$\checkmark$ Rollout proceeding under NBN Co 
NBN as Next Gen model?

- Role of government investment?

- Role of competition?

- Role/evolution of ISPS 


\section{Noam: Telecom 1.0 to 3.0}

- "Selling Telstra is actually about completing the transition from telecommunications being provided by a government department, the Post Master General, to telecommunications being provided by a multitude of nimble private sector interests" Communications Minister Coonan (2005)

- "many of the competitors that entered the openly competitive telecoms business were just as enthusiastic about the federal government's April 2009 announcement of a big plan for a public private partnership to build and operate an open access fibre national broadband network. This would be a new kind of monopoly fixed line network. The state would be in charge. It would not be Just Another Network, vulnerable to the creative destruction of a competitive market, but a Network for the Ages." Given (2009)

Noam, E. M. (2010). Regulation 3.0 for Telecom 3.0. Telecommunications Policy, 34 (1-2), 4-10.

Coonan, H. (2005). Connect Australia: Future Proofing the Nation. Sydney Papers, 17 (3-4), 140-151.

Given, J. (2009). Bothering About Broadband - Review Essay. Media International Australia, 132, 118-132. 


\section{Is a \$43 B investment a good idea?}

- Probably won't be $\$ 43 B$, but NBN Co CEO says "at least \$26B"

- Price of structural separation, 'taming' the incumbent?

- How to evaluate cost-benefit for this sort of 'nation building' exercise?

- Was there evidence of market failure to warrant massive intervention? Pressing need for network to support gov't apps?

NBN Co head Quigley quoted in Battersby, L. (2010, 28 June). Telstra Looks to Life after Fixed Phone Lines. Sydney Morning Herald. from http://www.smh.com.au/ business/telstra-looks-to-life-after-fixed-phone-lines-20100627-zbzs.html 


\section{What about competition?}

- Is facilities-based competition for next gen infrastructure dead?

- Open access networks instead of separate cable/ telco fibre? What about wireless? (both/and)

-What does it mean to compete in an open access network?

- Current structure sees NBN Co monopoly over passive and active layers, other models elsewhere - what makes sense? at what time? (phased competition?) 


\section{What about ISPs?}

- Is internet service provision becoming a commodity?

- Will everyone eventually simply have a seamless internet connection?

- If objective of competition was to differentiate and innovate, is this required when we've implemented the 'end game' solution?

- Other services, changing industry structure? 


\section{There are many more questions.}

\section{To be continued...}

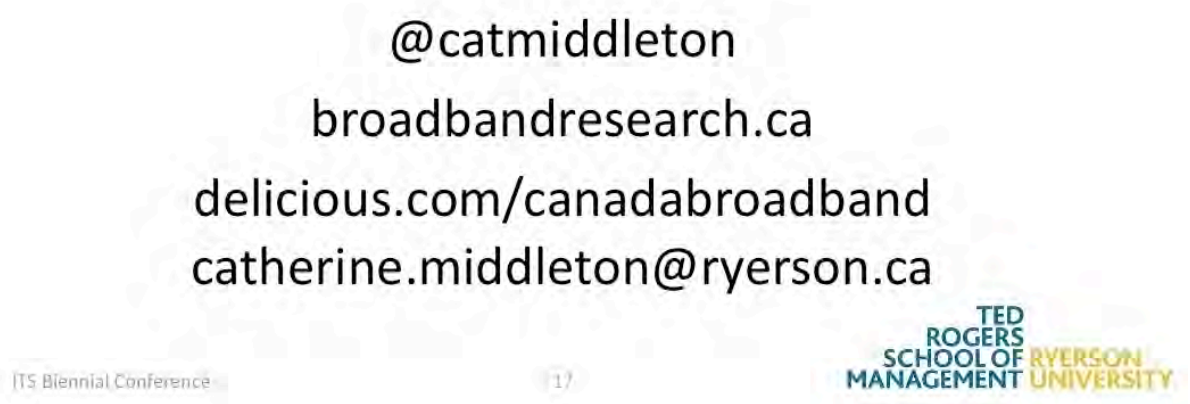

